\title{
Can Seeds Help to Expel Parasites? A Comment on the Garber-Kitron (1997) Hypothesis
}

\author{
Eckhard W. Heymann
}

Received: 5 February 2013 / Accepted: 14 February 2013 / Published online: 8 March 2013

(C) The Author(s) 2013. This article is published with open access at Springerlink.com

\section{Introduction}

Like many other primates, moustached and saddle-back tamarins (Saguinus mystax and Saguinus nigrifrons; previously Saguinus fuscicollis nigrifrons: Matauschek et al. 2011) are seed dispersers for a large number plant species whose fruits they exploit for food (Culot 2009; Garber 1986; Knogge and Heymann 2003). Tamarins consistently swallow seeds ( $c$. $95 \%$ of fecal samples contain seeds) that are often very large in relation to the tamarins' body size (Garber and Kitron 1997; Knogge and Heymann 2003). Mean length and width of seeds ( \pm SD) recovered from feces was $1.75 \pm 0.59 \mathrm{~cm}$ (maximum: $2.35 \mathrm{~cm}$ ) and $0.74 \pm 0.32 \mathrm{~cm}$ (maximum: $1.31 \mathrm{~cm}$ ) in Saguinus mystax, and $1.74 \pm 0.56 \mathrm{~cm}$ (maximum: $2.33 \mathrm{~cm}$ ) and $0.75 \pm 0.31 \mathrm{~cm}$ (maximum: $1.35 \mathrm{~cm}$ ) in S. nigrifrons (Knogge and Heymann 2003). Heymann (1992) speculated that large seeds may function physiologically as a kind of "roughage" and that the lack of continuous gut stimulation may be one cause of the high prevalence of gastrointestinal diseases in captive tamarins (Clapp et al. 1988; Gozalo and Montoya 1992), which contrasts to the low prevalence in wild tamarins (Wood et al. 1989).

Seeds do not provide a nutritional benefit but rather are ballast that occupies much space in the gastrointestinal tract (Garber and Kitron 1997). Therefore, seeking an adaptive explanation of seed swallowing, Garber and Kitron (1997) proposed dislodging and expelling intestinal parasites, particularly the highly damaging acanthocephalan hookworm Prosthenorchis elegans, as the major function. Huffman (1997; see also Huffman and Caton 2001; Huffman et al. 1996) and Wrangham (1995) had provided evidence for the mechanical expulsion of parasites through swallowing of entire leaves in chimpanzees (Pan troglodytes). Garber and Kitron (1997) based their argument on the high prevalence (and lethality; Cosgrove et al. 1968) of Prosthenorchis elegans infections in captive tamarins and low prevalence in

Electronic supplementary material The online version of this article (doi:10.1007/s10764-013-9667-y) contains supplementary material, which is available to authorized users.

\section{E. W. Heymann $(\bowtie)$}

Abteilung Verhaltensökologie \& Soziobiologie, Deutsches Primatenzentrum, 37077 Göttingen, Germany e-mail: eheyman@gwdg.de 
the wild. Under the Garber-Kitron hypothesis, the following predictions can be made:

1) At the group level, the prevalence of infections with Prosthenorchis elegans should correlate negatively with the proportion of fecal samples per group that contain seeds.

2) At the individual level, individuals infected with Prosthenorchis elegans should swallow seeds more often than noninfected individuals. Because rates of seed swallowing itself are difficult to determine, I use the number of fecal samples per individual containing seeds as a surrogate variable.

I used data from field studies of a population of Saguinus mystax and S. nigrifrons at the Estación Biológica Quebrada Blanco (EBQB), in northeastern Peruvian Amazonia since 1994 to test these predictions.

\section{Methods}

Müller (2007) and Wenz et al. (2010) conducted parasite analyses on three mixedspecies groups of Saguinus mystax and S. nigrifrons at EBQB in 2002-2003 and 2007, respectively. Wenz et al. (2010) also examined a mixed-species group of Saguinus mystax and $S$. nigrifrons living close to Diamante, a village ca. $1.5 \mathrm{~km}$ from EBQB. Müller (2007) analyzed 430 fecal samples randomly selected from a total of 1907 samples, with 4-16 samples from nonconsecutive days per individual. Wenz et al. (2010) examined a total of 356 samples, at least three samples per individual from nonconsecutive days. Müller (2007) noted the presence or absence of seeds $>0.5 \mathrm{~cm}$ length in samples selected for analyses. Both studies determined the prevalence of several gastrointestinal parasites, including Prosthenorchis elegans, in individually assigned fecal samples (for methodological details see Müller 2007 and Wenz et al. 2010). I used prevalence data from Müller (2007) and calculations of the proportion of faecal samples containing seeds from Müller's original data. To test prediction 1 I used Kendall's $\tau$, which allows correlation analyses with small sample sizes, in WinSTAT ${ }^{\circledR}$ version 2009.1. To test prediction 2 I used the Mann-Whitney $U$-test in Statistica 9.0 (StatSoft 2009) to compare the proportion of samples containing seeds between infected and noninfected individuals.

Researchers studying seed dispersal by Saguinus mystax and S. nigrifrons in 1994 1995 (Knogge and Heymann 2003) and reproductive hormones in male (Huck et al. 2005) and female (Löttker et al. 2004) S. mystax in 2000-2001 collected 2470, 369, and 562 fecal samples, respectively. Although these studies did not look for parasites in particular, the presence of adult Prosthenorchis elegans would not have been dismissed because they are 2-4 cm long (Mehlhorn 2001) and all samples were examined carefully for other analyses.

\section{Results}

We found no adult Prosthenorchis elegans in fecal samples in any of the studies. Although we cannot be sure whether individuals examined during the seed dispersal 
and hormonal studies were infected with Prosthenorchis elegans, the fact that most individuals included in the hormonal studies were also included in the parasitological study by Müller (2007) and the consistency of prevalence of $P$. elegans in the studies by Müller (2007) and Wenz et al. (2010) suggest that some proportion of the tamarin population is always infected with $P$. elegans. Interestingly, comparison of the studies by Müller (2007) and Wenz et al. (2010) reveals strong intergroup variation in the prevalence of Prosthenorchis elegans, with groups living near the human village (group D) and the field camp (group 1) showing the highest prevalence in both tamarin species (Table I).

The prevalence of Prosthenorchis elegans infections did not correlate with the proportion of fecal samples that included seeds (Kendall's $\tau=0.138, N=6, P=0.349$ ). The proportion of fecal samples that included seeds $>0.5 \mathrm{~cm}$ did not differ between infected and noninfected tamarins $\left(\right.$ median $_{\text {infected }}=70.0 \%$, range: $55.6-80.0 \%, N=7$; median $_{\text {noninfected }}=71.4 \%$, range: $20-100 \%, N=31$; Mann-Whitney $U=101.0, Z=$ $0.26, P=0.792)$.

\section{Discussion}

None of the predictions derived from the Garber-Kitron hypothesis is supported. Another argument against the Garber-Kitron hypothesis results from the fact that Prosthenorchis elegans does not move around freely in the intestinal content, but has its spiny head deeply burrowed into the gut mucosa (see Fig. 1 in Müller et al. 2010).

Table I Prevalence of infections with Prosthenorchis elegans in mixed-species groups of Saguinus mystax $(\mathrm{Sm})$ and Saguinus nigrifrons $(\mathrm{Sn})$ for details of group composition see Supplementary Tables S1 and S2

\begin{tabular}{lllll}
\hline Group & Species & $\begin{array}{l}\text { Prevalence [\%] (no. of individuals } \\
\text { infected/no. of individuals examined) }\end{array}$ & $\begin{array}{l}\text { \% of fecal samples } \\
\text { containing seeds } \\
\text { (no. of samples examined) }\end{array}$ \\
\cline { 3 - 4 } & & Müller (2007) & Wenz et al. $(2010)$ & \\
\hline 1 & $S m$ & $33.3(2 / 6)$ & $50.0(3 / 6)$ & $70.2(37)$ \\
& $S n$ & $50.0(3 / 6)$ & $50.0(2 / 4)$ & $58.6(58)$ \\
3 & $S m$ & $12.5(1 / 8)$ & $20.0(1 / 5)$ & $48.6(74)$ \\
& $S n$ & $16.7(1 / 6)$ & $16.7(1 / 6)$ & $68.8(64)$ \\
& $S m$ & $0.0(0 / 7)$ & $0.0(0 / 6)$ & $63.6(77)$ \\
D & $S n$ & $0.0(0 / 5)$ & $0.0(0 / 3)$ & $62.3(61)$ \\
& $S m$ & - & $50.0(3 / 6)$ & - \\
\hline
\end{tabular}

Groups 1-3 are from EBQB, group D from the village Diamante

${ }^{\mathrm{a}}$ The number of individuals examined is identical to group size

${ }^{\mathrm{b}}$ From samples collected by Müller (2007) in 2002-2003. Figures are lower than the $95 \%$ reported by Knogge and Heymann (2003) and an underestimate, as for the purpose of the parasitological study we only noted whether seeds larger $>0.5 \mathrm{~cm}$ length were present that might affect quantitative parasitological parameters (such as egg counts per unit faecal matter) 
This makes mechanical dislocation and expelling by seeds unlikely or at least quite difficult; dislocation would result in deep wounds in the gut wall. This interpretation is supported by findings of Huffman et al. (1996) on the physical effect of leaf swallowing on parasites in chimpanzees: Whereas Oesophagostomum stephanastomum, a parasite species with only loose attachment to the intestinal mucosa, was expulsed through leaf swallowing, Strongyloides fülleborni and Trichuris trichiura, both species with firm attachment to the intestinal mucosa, were unaffected.

In conclusion, the curative function hypothesis of seed swallowing is highly unlikely. The alternative hypotheses proposed by Garber and Kitron (1997) reducing time tamarins spent exposed in the canopy (and thus exposed to aerial predators) and increasing feeding efficiency by swallowing seeds along with the adhering pulp — are more likely, but await testing.

Acknowledgments I am indebted to the anonymous reviewers for very constructive and helpful criticism on an earlier version of the manuscript. All studies from which data are included in this article were conducted under authorization from the Dirección Regional de Recursos Naturales in Iquitos and the Instituto Nacional de Recursos Naturales (INRENA) in Lima, respectively. Studies by C. Knogge, P. Löttker, M. Huck, and B. Müller were supported by grants from the Deutsche Forschungsgemeinschaft (DFG) to the author (He 1870/3-[1-3], He 1870/10-[1,2], He 1870/13-[1-3]).

Open Access This article is distributed under the terms of the Creative Commons Attribution License which permits any use, distribution, and reproduction in any medium, provided the original author(s) and the source are credited.

\section{References}

Clapp, N. K., Henke, M. L., Lushbaugh, C. C., Humason, G. L., \& Gangaware, B. L. (1988). Effect of various biological factors on spontaneous marmoset and tamarin colitis. A retrospective histopathological study. Digestive Diseases and Sciences, 33, 1013-1019.

Cosgrove, G. E., Nelson, B., \& Gengozian, N. (1968). Helminth parasites of the tamarin, Saguinus fuscicollis. Laboratory Animal Care, 18, 654-656.

Culot, L. (2009). Primary seed dispersal by two sympatric species of tamarins, Saguinus fuscicollis and Saguinus mystax, and post-dispersal seed fate. Doctoral dissertation, Université de Liège.

Garber, P. A. (1986). The ecology of seed dispersal in two species of callitrichid primates (Saguinus mystax and Saguinus fuscicollis). American Journal of Primatology, 10, 155-170.

Garber, P. A., \& Kitron, U. (1997). Seed swallowing in tamarins: evidence of a curative function or enhanced foraging efficiency? International Journal of Primatology, 18, 523-538.

Gozalo, A., \& Montoya, E. (1992). Mortality causes of the moustached tamarin (Saguinus mystax) in captivity. Journal of Medical Primatology, 21, 35-38.

Heymann, E. W. (1992). Can seeds help to maintain gastrointestinal health in tamarins? Laboratory Primate Newsletter, 31(3), 1-2.

Huck, M., Löttker, P., Heymann, E. W., \& Heistermann, M. (2005). Characterization and social correlates of fecal testosterone and cortisol excretion in wild male moustached tamarins (Saguinus mystax). International Journal of Primatology, 26, 159-179.

Huffman, M. A. (1997). Current evidence for self-medication in primates: a multidisciplinary perspective. Yearbook of Physical Anthropology, 40, 171-200.

Huffman, M. A., \& Caton, J. M. (2001). Self-induced increase of gut motility and the control of parasitic infections in wild chimpanzees. International Journal of Primatology, 22, 329-346.

Huffman, M. A., Page, J. E., Sukhdeo, M. V. K., Gotoh, S., Kalunde, M. S., Chandrasiri, T., et al. (1996). Leaf-swallowing by chimpanzees, a behavioral adaptation for the control of strongyle nematode infections. International Journal of Primatolology, 17, 475-503.

Knogge, C., \& Heymann, E. W. (2003). Seed dispersal by sympatric tamarins, Saguinus mystax and Saguinus fuscicollis: diversity and characteristics of plant species. Folia Primatologica, 74, 33-47. 
Löttker, P., Huck, M., Heymann, E. W., \& Heistermann, M. (2004). Endocrine correlates of reproductive status in breeding and nonbreeding wild female moustached tamarins. International Journal of Primatology, 25, 919-937.

Matauschek, C., Roos, C., \& Heymann, E. W. (2011). Mitochondrial phylogeny of tamarins (Saguinus, Hoffmannsegg 1807) with taxonomic implications for the S. nigricollis species group. American Journal of Physical Anthropology, 144, 564-574.

Mehlhorn, H. (2001). Encyclopedic reference of parasitology (2nd ed.). Heidelberg: Springer.

Müller, B. (2007). Determinants of the diversity of intestinal parasite communities in sympatric New World primates (Saguinus mystax, Saguinus fuscicollis, Callicebus cupreus). Doctoral dissertation, Tierärztliche Hochschule Hannover.

Müller, B., Mätz-Rensing, K., Pérez Yamacita, J. G., \& Heymann, E. W. (2010). Pathological and parasitological findings in a wild red titi monkey, Callicebus cupreus (Pitheciidae, Platyrrhini). European Journal of Wildlife Research, 56, 601-604.

StatSoft, Inc. (2009). STATISTICA für Windows (Software-System für Datenanalyse), Version 9.0. www.statsoft.com.

Wenz, A., Heymann, E. W., Petney, T. N., \& Taraschewski, H. F. (2010). The influence of human settlements on the parasite community in two species of Peruvian tamarin. Parasitology, 137, 675-684.

Wood, J. D., Peck, O. C., Sharma, H. M., Mekhjian, H. S., Stone, D. W., Hernandez-Camacho, J., et al. (1989). Incidence of colitis and colon cancer in feral cotton-top tamarins (Saguinus oedipus). Gastroenterology, 96, A551.

Wrangham, R. W. (1995). Relationship of chimpanzee leaf-swallowing to a tapeworm infection. American Journal of Primatology, 37, 297-303. 